\title{
The Relationship of Transformational and Transactional Principal Leadership on Teacher Job Satisfaction and Secondary Student Performance in Subang Jaya, Malaysia
}

\author{
Nazlina Mirsultan1, Thangaveloo Marimuthu² \\ ${ }^{1}$ INTI International College Subang, Subang Jaya, Malaysia \\ ${ }^{2}$ School of Education and Cognitive Sciences, Asia e University, Kuala Lumpur, Malaysia \\ Email: nalimirkhan@hotmail.com
}

How to cite this paper: Mirsultan, N., \& Marimuthu, T. (2021). The Relationship of Transformational and Transactional Principal Leadership on Teacher Job Satisfaction and Secondary Student Performance in Subang Jaya, Malaysia. Open Journal of Leadership, 10, 241-256.

https://doi.org/10.4236/oj1.2021.103016

Received: August 10, 2021

Accepted: September 27, 2021

Published: September 30, 2021

Copyright $\odot 2021$ by author(s) and Scientific Research Publishing Inc. This work is licensed under the Creative Commons Attribution International License (CC BY 4.0).

http://creativecommons.org/licenses/by/4.0/

(c) (i) Open Access

\begin{abstract}
This study reviews the perceptions of teachers as to how the leadership of their principal affects their job satisfaction at public secondary schools and in turn, the effect it has on students' academic performance. This research concentrates on how teacher's perceptions of their principal's leadership style enhance teachers' job satisfaction. The purpose of this study was to examine the unique impact that school principals have on teacher job satisfaction and finding which specific leadership practices were associated with teacher job satisfaction. The researcher tried to explore transformational and transactional leadership styles to find out, which was more effective leadership style as principal in public secondary schools. It was also to confirm that knowledge and perceptions of teachers can help principals to create a better working environment and helps to understand the needs of their teachers. The result of this study indicated that principal leadership style has a significant relationship to teacher job satisfaction in schools. Thus, the findings of this study provide a better understanding of teacher job satisfaction and student performance can be influenced by the principal leadership styles.
\end{abstract}

\section{Keywords}

Principal Leadership, Transformational \& Transactional, Teacher Job Satisfaction

\section{Introduction}

Teacher's job satisfaction is influenced by the leadership style implemented by 
the principal, which simultaneously affects students' performance. There are several leadership styles used by various school principles across the globe but there is no clarity on which leadership style is the most effective one for better job satisfaction and student performance. Implementing the most effective leadership style has remained a problem to many school principals in many countries, including Malaysia. Little research has been done on factors affecting students' performance and teachers' job satisfaction (Ismail, 2010), but there is lacking research on the most effective leadership style. Due to different leadership styles applied by different school principals, there is mixed performance; some struggling while others performing better (Ibrahim et al., 2013). While the country continues to develop industrially the expectations of teachers, parents; and the job market continues to increase. There are questions on the sustainability of the Malaysian education system to provide the best education environment for both teachers and students while facing the challenges of this new millennium (MEB, 2013-2025).

It is highly questionable that stressed teachers who faced job dissatisfaction with deprived family and work balance will develop quality students. The lack of understanding of the problems and issues of the teachers is probably due to less awareness and realization regarding the issues. This study is designed to make a comparison between the transactional and transformational styles of leadership among principals and the job satisfaction and how it is related to the performance of students among public secondary schools specifically in Subang Jaya, Malaysia.

According to (Waters, 2013), studies have shown the presence of the relationship between the leadership practices of principals and the perception of teachers. It concern's teachers who are not adequately satisfied may in turn influence the performance of students' achievements in a classroom.

Prior studies affirm that principals' leadership effectiveness also depends on how the teachers perceive the leadership style implemented by the principal (Verma, 2012). The main role of the school principal is to direct teachers on the daily endeavors to achieve school goals and missions but there are cases in which some principals implement inappropriate leadership styles in which they used as tools instead of working collaboratively as partners to meet administrative and student's needs (Viswanathan, 2015). For this reason, school leadership including the principal plays a vital role in guiding the teachers to do what is expected and keeping them motivated. To be academic centers of excellence, school principals are therefore encouraged to put in proactive leadership styles that are engaging, motivating, and empowering to raise levels of job satisfaction who play a key role in school performance.

The research objectives of this study include examining the relations between principal's leadership style and the teachers' job satisfaction and how that influences the students' performance.

\section{Literature Review}

Leadership has remained an area of interest among different people. From vari- 
ous studies, there is proof that leadership influences performance and effective leadership uses better leadership practices as tools to improve their performances. Further insights point out that good leadership inspires workers while other studies done in schools indicate that leadership styles implemented by principals affect the ethos of the institution which in turn has a significant effect on the overall performance.

In education, two dominant leadership styles commonly used are 1) transformational and 2) transactional leadership styles. From the literature, these two leadership styles are the best suited to examine school principals.

\subsection{Transactional Leadership}

Transformational leadership was presented by James McGregor Burns in his publication in 1978. He analyzed the abilities of leaders based on their engagement towards workers' inspiration to higher levels of commitment and ethical quality. It was discovered by (Robinson et al., 2008), that commitment to a shared objective changed the company by improving the capacity of the workers to function as a team to resolve issues and accomplish companies' targets. This leadership style emphasizes the relationship between workers and their respective leaders. In this case, leaders are tasked to put in practice high levels of moral standards, inspire the followers, and encourage them to work towards a common goal (Ibrahim et al., 2013).

Collaboration, empowerment, and authenticity are vital characters of transformational leaders. They believe that the success of the organization cannot be achieved by working for themselves but will require collaborative help from other stakeholders of the organization. Empowerment and motivation is the main approach used and most transformational leaders include workers in the decision-making process and planning of the organization. This makes workers feel like co-owners of the organization, not just mere employees. When teachers are incorporated in decision making process and planning of the institution, teachers are empowered to work out their best since they fully understand the expectations needed. Transformational leaders build a cohesive bond with their subordinates making them feel they have a clear sense of belonging. When such a relationship exists and people are moving as a team, it is easier to ride over any challenges on the way. A good leader recognizes he cannot do it all alone, but needs support and commitment from others.

Transformational leadership style derived as a mixture of other minor theories. For instance, the participatory theory coined by (Lewin, 1946) emphasizes that several minds can be able to arrive at a better solution if they work out collaboratively. Transformational leadership is, therefore, an inclusive leadership style that transforms teachers' performance and generally the school.

Transformational leadership impacts real transformation of dispositions and organizational assumptions of individuals inspiring responsibility of company's objective, methodologies, as well as mission. This leadership style thinks about the principal's conduct, characteristics and incorporates situational and possibil- 
ity factors.

Leaders applying transformational leadership are good at inspiring, influencing, and mentoring their followers hence creating great effects on attitudinal changes. Studies were done by (Bass et al., 1985) who expected Maslow's hierarchy needs (Maslow, 1943) came up with the following factual transformational leadership ideologies as shown in Table 1 below.

\subsection{Transactional Leadership}

The transactional theory determines that leaders are authoritative, domineering, action-based, and normally interested in watching out for themselves. Transactional leadership looks at how followers communicate with their leaders, adhere to leaders' expectations so that they can be awarded, praised, or avoid punishment (Khan et al., 2011). In this leadership style, leaders use a variety of incentives to keep followers motivated in the firm. Rewards, as well as punishment, are common in this leadership style as major drivers for employee performance. Transactional leaders focus their energies on task culmination and depend on hierarchical prizes and disciplines to affect employee performance, with remuneration being dependent upon the adherents doing the jobs and tasks as characterized in this leadership type. These leaders use discipline as a ramification for helpless work and adverse outcomes and awards for job completion and positive outcomes. Studies show that this leadership style stresses more on the lower level of human necessities by zeroing in on certain work completion. Transactional leadership centers more on moving and empowering the subordinates through the trading of remunerations for their respective performances.

The view of transactional leaders towards their workers is that their inspiration is gotten from being compensated. Therefore, exchanges are continually between the leader and the workers to characterize in what way occupations done

Table 1. Attributes of a transformational leader (Bass et al., 1985, 1990).

\begin{tabular}{|c|c|}
\hline Functional Attributes & Accompanying Attributes \\
\hline Idealized Influence (II) & $\begin{array}{ll}\text { - } & \text { Trust } \\
\text { - } & \text { Vision } \\
\text { - } & \text { Risk-sharing } \\
\text { - } & \text { Respect } \\
\text { - } & \text { Integrity }\end{array}$ \\
\hline Inspirational Motivation (IM) & $\begin{array}{ll}\text { - } & \text { Commitment to goals } \\
\text { - } & \text { Modeling } \\
\text { - } & \text { Enthusiasm } \\
\text { Communication }\end{array}$ \\
\hline Intellectual Stimulation (IS) & - $\quad$ Rationality \\
\hline Individualized Consideration (IC) & $\begin{array}{ll}\text { - } & \text { Personal attention } \\
\text { - } & \text { Problem solving } \\
\text { - } & \text { Listening } \\
\text { - } & \text { Mentoring } \\
\text { - } & \text { Empowering }\end{array}$ \\
\hline
\end{tabular}


and the prizes that will be concurred for fruitful consummation and discipline in case tasks are uncompleted. Transactional leaders have likewise been observed to act naturally keen on thinking often more about their own advantage than imparting the advantages to the workers. Then again, transactional leaders stress inborn inspirations and individual development among their devotees. They build up a dream while motivating, providing trust, and regard among the workers (Figure 1).

Transactional leaders are sometimes considered effective as they can finish set jobs via doing it by not involving other stakeholders in the organization; this kind of leader is viewed as somebody who is domineering, bossy, and controlling (Khan et al., 2011). The two styles of leadership are fundamental and relevant to different scopes of prerequisites. It suggests an effective school principal can use these practices in various circumstances and needs. The fundamental contrast between these two kinds of leadership is that transactional leadership is more worried about the details while the transformational principal will be worried about the entire condition of the organization.

Conditional authority centers around daily activities and on approaches to oversee and keep up with the state of affairs of business tasks. Notwithstanding, they do not stress building up the heading of the association and the manners by which the devotees can arrive at their objectives. Prizes are not founded on the association's whole condition.

Contrary to the transformational leadership perception, transactional leaders determined their environment according to personal aims and strategies in the initial phases of development. They inspire the followers by identifying their wants based on their performance and support. Transactional attributes give emphasis to functions and good relations in place of the desired rewards.

Constructively, transactional leadership envelops four sorts of behavioral practices. These four behavioral practices are in a spectrum of using both positive and negative approaches to keep workers motivated. The transactional style is supported by four key viewpoints, which include:

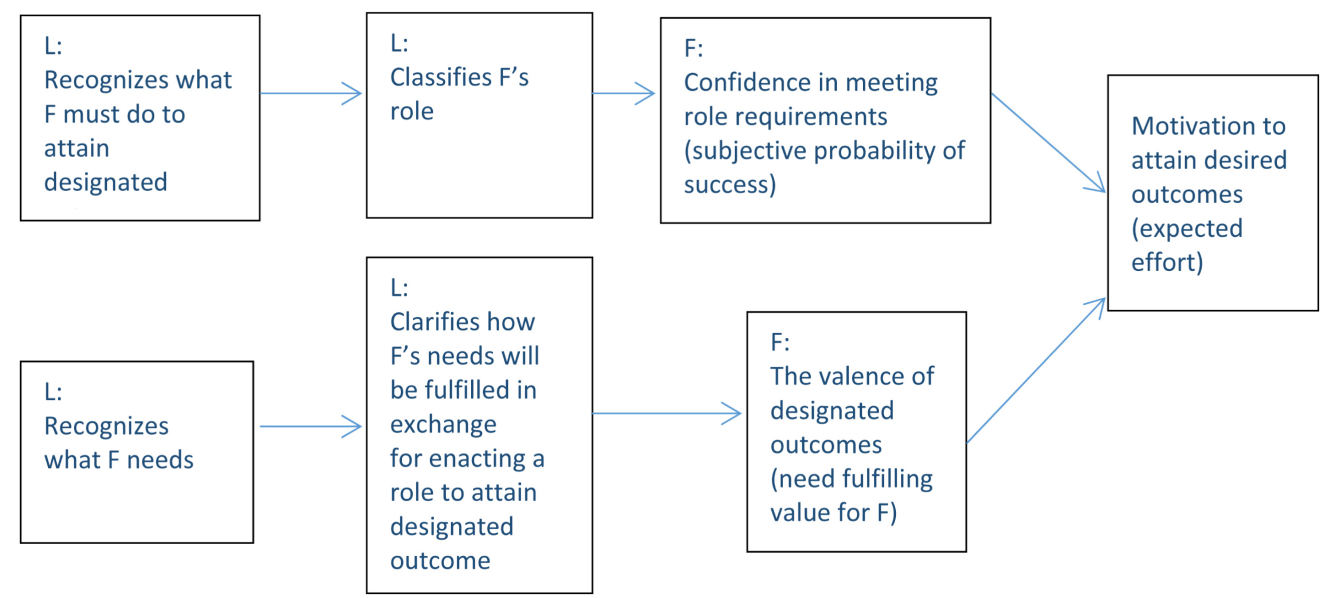

Figure 1. Transactional leadership $(\mathrm{L}=$ Leader and $\mathrm{F}=$ Follower $)($ Bass, 1990). 
1) Contingent reward identifies with a circumstance where the leader calls attention to the necessary results and allures with a type of remuneration when the outcomes are accomplished. This kind of leader takes emphasis on prizes and other punishable approaches viewed as encouraging feedback while punishments remain available for reinforcement (Paracha, et al., 2012).

2) Management by exception (active) leaders will possibly meddle when something turns out badly. They consistently evaluate employees' performance, change, and correct in their lines of duty (Ismail, 2010).

3) Management by exception (passive) type of leaders will wait for something to go wrong first. They will wait until the situation is worse or serious before they intervene.

4) Laissez-faire leaders are types of leaders who left the subordinates to make decisions by themselves. They are leaders who are afraid of making decision for the team and do not want to carry the responsibilities of being a leader. Laissez-faire leaders also do less to keep the subordinates motivated or empowered (Figure 2).

The literature review shows that school principals assume a vital role in fostering a labor force that is fulfilled (Hill, 2013). It is the responsibility of the principal to upgrade the method involved in learning and teaching responsibility and inspiration level to create and hold a labor force is satisfied. Most studies that have attempted to portray the attributes of a powerful and effective principal have found certain similarities (Hallinger, 2014). The majority of these studies express the accompanying characteristics for an effective principal in particular; the principal should be visionary, a leader, administrator, specialist, learner, strategist, designer, promoter, and lawmaker. The recognized qualities of an effective principal are attributes that a chief could embrace to be versatile to different circumstances that might emerge. In any case, the job of the principal persistently changes given the progressions in requests and inconveniences emerging from the current day-to-day school settings.

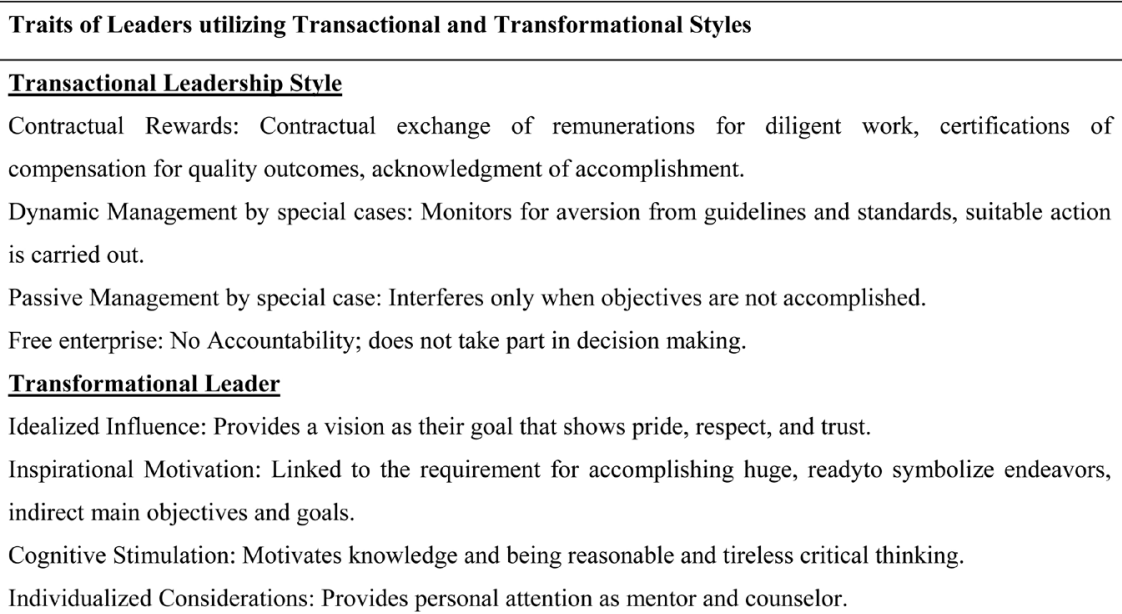

Figure 2. The differences between transactional and transformational leaders. Source: (Bass, 1990). 


\section{Research Method}

The study population consists of 260 teachers representing four public secondary schools from Subang Jaya, Malaysia. The MLQ (Multifactor Leadership Questionnaire) and the JSQ (Job Satisfaction Questionnaire) (Avolio \& Bass, 2004; Spector, 1995) were utilized to find out the respondents' demographic profiles.

A pilot test was conducted to verify the suitability as well as the validity and reliability of the instruments. The Multi-factor Leadership Questionnaire (MLQ) has been proven highly reliable instrument in measuring inter-relations, and dimensions of convergent and discriminative validity (Waters, 2013). All prior researches that have used MLQ were found to have a high level of validity for the leadership constructs of transformational and transactional style in the academic field (Waters, 2013). Job Satisfaction Questionnaire (JSQ) instrument is sound to be valid and reliable for use in the academic setting worldwide. In the past decade, many doctoral papers and studies have used this questionnaire for reference and utilization in association with teaching by academic organizations.

This study aimed at examining different styles of leadership and the effect on public secondary school teachers. Moreover, the study also included the examination of the relationship of the teachers' level of job satisfaction and the composite score according to the leadership style. Lastly, the study also examined the relationship between the Job Satisfaction Questionnaire (JSQ) and various leadership styles and the students' performance.

This quantitative research works on the two leadership types and the variables under job satisfaction that includes working environment, communication, promotions and many more.

The conceptual framework (refer to Figure 3) uses four major variables namely 1) independent variables-transformational and transactional leadership styles; 2) moderating variable-demographic profile of the teacher; 3) mediating variable-teachers' overall job satisfaction; and 4) dependent variable-students' performance. The moderating variable proposed in this study is the demographic variable of teachers; it is to examine which teachers' demographic variables affect the relations. The mediating variable has a function of decreasing and increasing the independent variable, which in turn affects the dependent variable. For instance, the performance of students could be hard to change only by shifting the leadership styles of principals; however, this could be done through committed teachers who would be better able to affect the students' performance.

\section{Research Questions and Hypotheses}

This study was conducted to answer the following questions:

Q1. To what extent does job satisfaction vary by teacher demographic?

Q2. What is the rate between teachers' demographic factors and students' performance? 


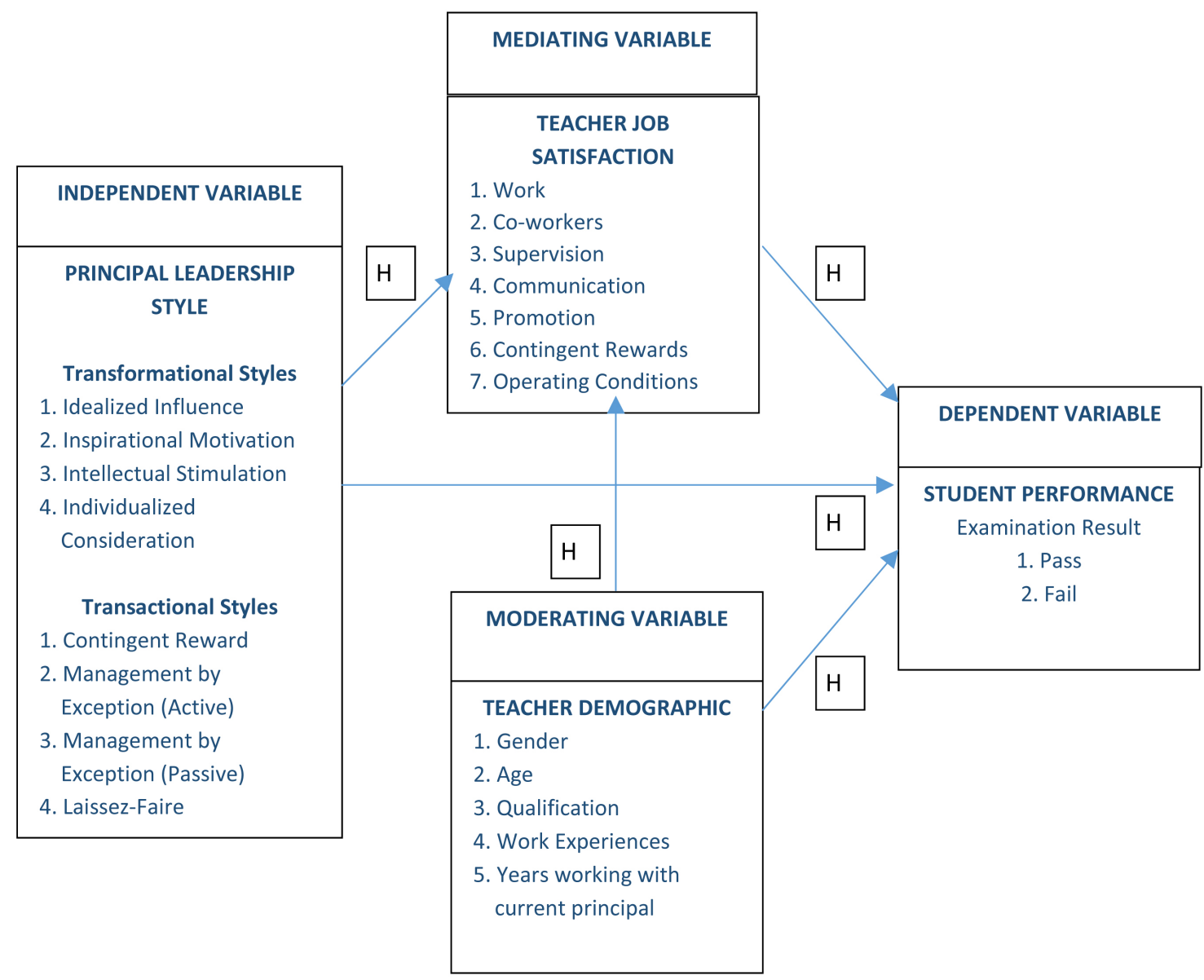

Figure 3. Conceptual framework of the study.

Q3. Does teachers' job satisfaction support students' performance?

Q4. In what ways do teachers' perceptions of principal leadership style influence their job satisfaction?

Q5. Does a principal behavior justify students' performance in school?

Below are the Research Hypotheses:

\begin{tabular}{|c|c|c|}
\hline Hypothesis & Structural Relationship & Relationship \\
\hline H1 & $\begin{array}{l}\text { Teacher Demographic Factors } \rightarrow \\
\text { Teacher Job Satisfaction }\end{array}$ & $\begin{array}{l}\text { Teacher Demographic Factors has a positive } \\
\text { influence on teacher job satisfaction. }\end{array}$ \\
\hline $\mathrm{H} 2$ & $\begin{array}{l}\text { Teacher Demographic Factors } \rightarrow \\
\quad \text { Student Performance }\end{array}$ & $\begin{array}{l}\text { Teacher Demographic Factors has a positive } \\
\text { influence on student performance. }\end{array}$ \\
\hline H3 & $\begin{array}{l}\text { Teacher Job Satisfaction } \rightarrow \\
\text { Student Performance }\end{array}$ & $\begin{array}{l}\text { Teacher Job Satisfaction has a positive } \\
\text { influence on Student Performance. }\end{array}$ \\
\hline $\mathrm{H} 4$ & $\begin{array}{l}\text { Principal Leadership Style } \rightarrow \\
\text { Teacher Job Satisfaction }\end{array}$ & $\begin{array}{l}\text { Principal Leadership Style has a positive } \\
\text { influence on Teacher Job Satisfaction. }\end{array}$ \\
\hline H5 & $\begin{array}{l}\text { Principal Leadership Style } \rightarrow \\
\quad \text { Student Performance }\end{array}$ & $\begin{array}{l}\text { Principal Leadership Style has a positive } \\
\text { influence on Student Performance. }\end{array}$ \\
\hline
\end{tabular}

The details of the research sample are shown below in Table 2 . 
Table 2. Research sample.

\begin{tabular}{cccccccc}
\hline No. Schools & $\begin{array}{c}\text { Teachers } \\
\text { in each } \\
\text { school }\end{array}$ & $\begin{array}{c}\text { participated } \\
\text { in the } \\
\text { survey from } \\
\text { each school }\end{array}$ & $\begin{array}{c}\text { Gender of Teachers } \\
\text { participated in } \\
\text { the survey }\end{array}$ & $\begin{array}{c}\text { Principal's } \\
\text { Gender }\end{array}$ & $\begin{array}{c}\text { Number } \\
\text { of Students }\end{array}$ \\
\hline 1 & School 1 & 76 & 60 & 7 & 53 & Female & 1122 \\
2 & School 2 & 80 & 65 & 13 & 52 & Female & 1014 \\
3 & School 3 & 61 & 50 & 4 & 46 & Female & 854 \\
4 & School 4 & 133 & 85 & 20 & 65 & Female & 1718 \\
\hline
\end{tabular}

Data collection used a survey using two instruments with three sections namely, 1) A demographic questionnaire; 2) Multi-factor Leadership Questionnaire (MLQ); 3) Job Satisfaction Questionnaire (JSQ). The initial stage in this study was to gain permission from principals of selected schools. A greeting letter accompanied the questionnaires to the instructors mentioning their consent of participating in the study. The teachers were made to comprehend that interest in the review meant that their assent and that the reaction is intentional with no impulse to take part. The schools and instructors were guaranteed of their responses being kept classified. The researcher collected the completed questionnaires from all the participating schools herself. A few kinds of tests were done regarding the research hypotheses. They were utilized to total the individual response dependent on leadership and job fulfillment. Participant's information was recovered from factor and mean scores. The inferential procedures including the free Chi-square, correlations, and various setbacks were used to break down the information and for hypothesis testing.

\section{Results}

Two hundred and sixty (260) teachers from four public secondary schools participated in the survey and completed the questionnaire successfully. There are nine (9) existing secondary public schools in Subang Jaya. The total population of teachers in all those nine schools is 796 . The percentage of teachers involved in this study is $33 \%$ of the total population. Table 3 below provides details of the respondents' demographic that were involved in this study.

The leadership style of principals' results in the participating schools is provided in Table 4 below.

Principal who adapted to transformational leadership style results in higher teacher's job satisfaction as compared to transactional leadership style (refer to Table 5).

Table 6 provide details of Pearson's Correlation for variables of Multi-factor Leadership Questionnaire (MLQ); and (3) Job Satisfaction Questionnaire (JSQ).

Regression analysis of Job Satisfaction and variable of Leadership were conducted in the study and result is shown in Table 7 below. 
Table 3. Demographics for respondents.

\begin{tabular}{|c|c|c|c|}
\hline Variables & Description & Respondent & Percentage (\%) \\
\hline \multirow{2}{*}{ Gender } & Male & 44 & $16.9 \%$ \\
\hline & Female & 216 & $83.1 \%$ \\
\hline \multirow{8}{*}{ Age } & 25 to 30 & 48 & $18.5 \%$ \\
\hline & 31 to 35 & 47 & $18.1 \%$ \\
\hline & 36 to 40 & 27 & $10.4 \%$ \\
\hline & 41 to 45 & 25 & $9.6 \%$ \\
\hline & 46 to 50 & 38 & $14.6 \%$ \\
\hline & 51 to 55 & 59 & $22.7 \%$ \\
\hline & 55 to 60 & 12 & $4.6 \%$ \\
\hline & $60+$ & 4 & $1.5 \%$ \\
\hline \multirow{3}{*}{ Qualification of Education } & Bachelor Degree & 163 & $62.7 \%$ \\
\hline & Master Degree & 95 & $36.5 \%$ \\
\hline & Doctorate Degree & 2 & $0.8 \%$ \\
\hline \multirow{4}{*}{ Years of Teaching } & 1 to 5 years & 56 & $21.6 \%$ \\
\hline & 6 to 10 years & 62 & $23.8 \%$ \\
\hline & 11 to 20 years & 101 & $38.8 \%$ \\
\hline & more than 20 years & 41 & $15.8 \%$ \\
\hline \multirow{2}{*}{ Years working with current principal } & 1 to 5 years & 134 & $51.5 \%$ \\
\hline & $6-10$ years & 126 & $48.5 \%$ \\
\hline
\end{tabular}

Table 4. Leadership styles of principals results.

\begin{tabular}{|c|c|c|c|c|c|c|}
\hline \multirow{2}{*}{$\begin{array}{c}\text { Variables } \\
\text { School }\end{array}$} & \multicolumn{2}{|c|}{ Transformational } & \multicolumn{2}{|c|}{ Transactional } & \multicolumn{2}{|c|}{ Total } \\
\hline & $\mathbf{N}$ & $\%$ & $\mathrm{~N}$ & $\%$ & $\mathbf{N}$ & $\%$ \\
\hline 1 & 35 & $58.30 \%$ & 25 & $41.70 \%$ & 60 & $23 \%$ \\
\hline 2 & 31 & $47.80 \%$ & 34 & $52.30 \%$ & 65 & $25 \%$ \\
\hline 3 & 27 & $54.10 \%$ & 23 & $46 \%$ & 50 & $19.20 \%$ \\
\hline 4 & 43 & $50.60 \%$ & 42 & $49.40 \%$ & 85 & $32.70 \%$ \\
\hline Total & 136 & $52.3 \%$ & 124 & $47.6 \%$ & 260 & $100 \%$ \\
\hline
\end{tabular}

Table 5. Leadership styles (MLQ) and job satisfaction (TJSQ) results.

\begin{tabular}{ccccccc}
\hline \multirow{2}{*}{ Leadership Styles-MLQ } & \multicolumn{7}{c}{ Job Satisfaction-TJSQ (28 item) } \\
\cline { 2 - 7 } & Satisfied & $\%$ & Dissatisfied & $\%$ & Total & $\%$ \\
\hline Transformational & 131 & $96.30 \%$ & 5 & $3.70 \%$ & 136 & $52.30 \%$ \\
Transactional & 75 & $60.50 \%$ & 49 & $39.50 \%$ & 124 & $47.70 \%$ \\
Total & 206 & $79.20 \%$ & 54 & $20.80 \%$ & 260 & $100 \%$ \\
\hline
\end{tabular}


Table 6. Pearson's correlations for variables of MLQ and TJSQ.

\begin{tabular}{|c|c|c|c|c|c|c|c|c|}
\hline \multirow{2}{*}{ Variables } & \multicolumn{4}{|c|}{ Transformational Leadership } & \multicolumn{4}{|c|}{ Transactional Leadership } \\
\hline & IF & $\mathrm{IM}$ & IS & IC & $\mathrm{CR}$ & MA & MP & LF \\
\hline Nature of work & 0.5 & 0.5 & 0.56 & 0.56 & 0.51 & 0.28 & 0.31 & 0.35 \\
\hline Supervision & 0.79 & 0.7 & 0.79 & 0.8 & 0.76 & -0.34 & -0.57 & -0.62 \\
\hline Co-workers & 0.5 & 0.4 & 0.45 & 0.5 & 0.41 & -0.24 & -0.34 & -0.36 \\
\hline Communication & 0.2 & 0.29 & 0.2 & 0.2 & 0.18 & -0.04 & -0.2 & 0.27 \\
\hline Promotion & 0.52 & 0.45 & 0.57 & 0.6 & 0.55 & -0.2 & -0.38 & -0.48 \\
\hline Rewards & 0.51 & 0.42 & 0.48 & 0.52 & 0.49 & -0.18 & -0.32 & -0.34 \\
\hline Operating Condition & 0.56 & 0.5 & 0.5 & 0.48 & 0.53 & -0.12 & -0.4 & -0.36 \\
\hline Job Satisfaction & 0.74 & 0.66 & 0.74 & 0.77 & 0.72 & -0.33 & -0.57 & -0.66 \\
\hline \multicolumn{9}{|c|}{$\mathrm{p}$ less than 0.01 level $\mathrm{p}$ less than 0.05 level (2-tailed) } \\
\hline \multicolumn{9}{|c|}{$\begin{aligned} \text { IF }=\text { Idealized Influence, } \mathrm{IM} & =\text { Inspirational Motivation, } \\
\text { IS }=\text { Intellectual Stimulation, } \mathrm{IC} & =\text { Individualized Consideration }\end{aligned}$} \\
\hline \multicolumn{9}{|c|}{$\begin{array}{c}\mathrm{CR}=\text { Contingent Reward } \mathrm{MA}=\mathrm{Management} \text { Active } \\
\mathrm{MP}=\text { Management Passive }, \mathrm{LF}=\text { Laissez-Faire }\end{array}$} \\
\hline
\end{tabular}

Table 7. Regression analysis of job satisfaction and variables of leadership change statistics.

\begin{tabular}{|c|c|c|c|c|c|c|c|c|c|c|}
\hline \multirow[b]{2}{*}{ Model } & \multirow[b]{2}{*}{$\mathrm{R}$} & \multirow[b]{2}{*}{$\mathrm{R}$} & \multirow[b]{2}{*}{$\begin{array}{c}\text { Adjusted } \\
\text { R }\end{array}$} & \multirow[b]{2}{*}{ Std. } & \multirow{2}{*}{$\begin{array}{c}\text { R Square F } \\
\text { Error of } \\
\text { Change }\end{array}$} & \multirow[b]{2}{*}{ Change } & \multirow{2}{*}{$\begin{array}{l}\text { Sig. } \\
\text { df1 }\end{array}$} & \multirow{2}{*}{$\begin{array}{c}\text { FDurbin- } \\
\text { df2 }\end{array}$} & \multirow[b]{2}{*}{ Change } & \multirow[b]{2}{*}{ Watson } \\
\hline & & & & & & & & & & \\
\hline 1 & 0.824 & 0.58 & 0.58 & 0.3 & 0.59 & 47 & 8 & 201 & 0 & 1.9 \\
\hline
\end{tabular}

The student performance of the four participating schools is as below in Table 8.

The overall results derived from this study are as follows:

1) There was no significant relationship between the teachers' demographic factors and job satisfaction.

2) There was no significant relationship between the teachers' demographic factors and performance of students.

3) There was no significant relationship between teachers' job satisfaction and performance of students.

4) There was a significant relationship between a principal's leadership styles and teachers' job satisfaction.

5) There was no significant relationship between a principal's leadership styles and performance of students.

The above results have shown that hypothesis one, hypothesis two, hypothesis three and hypothesis five were not supported by the data except hypothesis four. Hypothesis four has been proven valid, there was a statistically significant relationship between a principal's leadership styles and teachers' job satisfaction. 
Table 8. Student performance.

\begin{tabular}{cccccccc}
\hline Schools & $\begin{array}{c}\text { No. of } \\
\text { students } \\
\text { sat for test }\end{array}$ & $\begin{array}{c}\text { No. of } \\
\text { students } \\
\text { passed }\end{array}$ & $\%$ & $\begin{array}{c}\text { No. of } \\
\text { students } \\
\text { failed }\end{array}$ & $\%$ & $\begin{array}{c}\text { No. of } \\
\text { students } \\
\text { obtained 9As }\end{array}$ & $\%$ \\
\hline School 1 & 220 & 197 & $89.5 \%$ & 23 & $10.4 \%$ & 18 & $8.1 \%$ \\
School 2 & 115 & 96 & $83.4 \%$ & 19 & $16.5 \%$ & 13 & $11.3 \%$ \\
School 3 & 120 & 88 & $73 \%$ & 32 & $26.7 \%$ & 9 & $7.5 \%$ \\
School 4 & 212 & 185 & $87.2 \%$ & 27 & $12.7 \%$ & 16 & $7.5 \%$ \\
Total & $\mathbf{6 6 7}$ & $\mathbf{5 6 6}$ & $\mathbf{8 4 . 8 \%}$ & 101 & $\mathbf{1 5 . 1 \%}$ & $\mathbf{5 6}$ & $\mathbf{8 . 3 \%}$ \\
\hline
\end{tabular}

\section{Discussion}

The quantitative findings showed that more than half of the respondents ranked their own principals for more transformational traits in their leadership style compared to the transactional style. The findings clearly showed that the styles of leadership inter-mingle and a leader, are not completely transformational or transactional. Transformational and transactional leadership styles are distinctive processes; however, both are not mutually exclusive. Transformational leadership goes along well with the impacts of transactional leadership. Leadership behaviors both transactional as well as transformational are highly significant and valuable for various types of requirements. This shows that a successful leader in the education field uses both transactional and transformational traits as the situation demands.

Some teachers enjoy job satisfaction despite the style of leadership by the school principals. The majority of the teachers stated satisfaction working with others. This includes students, other teachers, and parents. In this case, the leadership of the principal in school does not have much of an influence on these teachers' job satisfaction. An elaborate job satisfaction factor, for example, the work itself, condition of operating, and coworkers were the real supporters of higher job satisfaction as every one of these elements got scores of more than the normal mean score. Measurements including communications, supervision, and rewards however received lower scores for job satisfaction compared to job dissatisfaction. These findings showed that respondents perceived work, coworkers, and conditions of operating caused a higher level of job satisfaction. However, the variables including communications, supervision, and rewards cause job dissatisfaction. Some teachers perceive their principal as ineffective as most of the time was spent on carrying out duties that should have been shared with others.

There was a significant link between the leadership styles and job satisfaction of teachers. There were a higher percentage of satisfied participants who were led by a transformational leader compared to being led by a transactional leader. Teachers as frontline workers are accountable for the student's success. Principals must be aware of how they affect this part of the process of education. Supporting the teachers and offering the teachers the opportunity to work together and to share ideas and practices that would benefit the students is an effective strategy. 
While school principals are one level removed from the classroom and therefore do not directly interact with students as much as teachers do, they do directly impact the school conditions necessary for teachers to be able to effectively carry out instruction leading to increased student achievement. As such, this study found that school leadership and student achievement are related, though this relationship is mediated by teacher action. This study suggests that effective school leadership leads to a more satisfying context, which leads to more job satisfaction among teachers, thereby strengthening their commitment to their work and to implementing classroom and instructional strategies that support students' learning, which in turn relates to increased student achievement.

A principal's ability to frame, convey, and sustain the school's purpose and goals is not enough. Effective leaders must have high expectations for staff and students that are reasonable and attainable. These expectations are based on trends in students' past academic performance and a clear and informed understanding of teacher performance, teachers' commitment to the school and its students. For example, at school where teachers are performing well and the level of student achievement is high, effective leaders would be likely to continue to monitor teacher performance while setting aggressive incremental increases in student achievement as a goal. However, in schools where teacher performance and student achievement are low, leader would be more likely to set measurable expectations related to instructional improvement and monitor it through teacher evaluation while simultaneously expecting student achievement to improve accordingly.

School leaders need to understand the importance and influence of outside stakeholders and the extent to which their engagement can contribute to better student outcomes. The stakeholders' influences extend to include those outside the school, such as community, organizations and parents. Teachers and parents can assume leadership roles to promote practices that will improve student learning, but their efforts are unlikely to come together in a focused, sustained way without effective leadership.

Besides, these outcomes additionally bolster the idea that activity fulfillment will be higher and teachers will be more joyful, instructive greatness will be advanced, and strong, mindful and restrained conditions will be continued when principals are rousing and inspirational.

\section{Conclusion}

The study found that teachers' demographics such as age, experience, and amount spend working with the principal, and qualifications had no huge relationship to teacher's work fulfillment. In this study, a large portion of the members are female when contrasted with males, there was a factual huge distinction between the sexual orientations. This outcome might be biased, as the number of female members was a third higher than that of the respondents. Nonetheless, the general result for the demographic factors had no significant effect on teach- 
er's satisfaction as earlier mentioned. The researcher likewise discovered that job satisfaction varies more in schools. This can be deciphered, as occupation fulfillment is an individual event, which indicates that teachers can fundamentally fluctuate as far as their fulfillment though they share comparative work spot and school attributes.

Furthermore, there's a weak relationship between demographic variables and performance of the students. Teacher's demographics factors like sexual orientation, age, qualification, and experience. More than a third of the teachers had a degree qualification and at least five years of experience in teaching.

It was also found that there is a weak relationship between teachers' work fulfillment and performance. However, it was acknowledged and believed that in case teachers are happier with their positions they can convey their duties substantially more productively and successfully. Moreover, this research study demonstrated that fulfilled educator does not guarantee palatable understudy execution. A significant part of the exploration on employment fulfillment and improved results has been doing business and industry. The same number of individuals will affirm, a school is not a business foundation and the results cannot be treated in a similar way (Aydin et al., 2013). The results for a school are its understudies and network. This is normally considered to be effective or not by test scores.

In any case, principals at school need to guarantee that they can give a superior workplace to teachers. Work environment conditions have generally been related in the direction of job satisfaction (Hallinger, 2014). Even though this research discovered there was a weak relationship between satisfaction and performance of the students, the learning environment in the classroom is affected by the teachers' role to make class decisions (Lawrence \& Vimala, 2012). The principal is tasked to empower teachers in the educational system for a better learning environment for students.

It was discovered that a strong relationship exists between leadership and job satisfaction. From this research, the transformational style of leadership contributed to higher job satisfaction than the transactional leadership style. Although, this does not mean that transformational leadership will guarantee job satisfaction. There are various unessential components drawn in with job satisfaction, and the top management cannot discard them. This is due to job satisfaction being a private entity and it depends on the individual interests for the teachers to be satisfied which varies from one person to another. In this way, it will be undeniably challenging for the principal to guarantee that every one of the teachers will be happy under their leadership.

Taking everything into account, this assessment discovered that there is a weak relationship between leadership and performance of students. This means that how a principal leads the school does not significantly affect the performance. This assessment shows leadership has no relationship with performance. The principal didn't influence the accomplishment of students. However, researchers argue that leadership has an effect (Clarke \& O'Donoghue, 2016). Al- 
though performance will not be affected directly by leadership, some other interceding factors like resources, facilities, and school environment may presumably influence students' performance in schools. Therefore, researchers conclude whatever the case, principal remains a central figure in school hence is responsible for both teachers' and student's performance and satisfaction (Abd-Hamid et al., 2012).

\section{Recommendations for Future Studies}

Firstly, it is recommended that a similar study be carried out in other parts of the country using a larger population sample and a variety of areas such as urban, semi-urban and rural. Such findings could ascertain if the findings of this study are replicable. If the studies are effective, similar studies with suitable adaptations could be executed, among institutions of higher education including universities and colleges.

The second recommendation is to conduct a qualitative component of this study. Future studies could include the implementation of findings using the qualitative approach, which could involve in-depth interviews, case studies, and focus group surveys with teachers and even heads of schools. This approach would add another dimension to provide a holistic finding to the area of leadership and job satisfaction in the educational setting. A subjective proportion of occupation fulfillment and the authority classes may gather a superior understanding about the insights of the educators of their feeling regarding the manner in which they are performing.

The third suggestion is center around moving educators at different professional stages. Discovering what persuades instructors at various professional stages would expand the extent of the present study. A longitudinal study that pursues educators in the start of their vocation as far as possible of their vocations in the case of resigning or just leaving the calling could offer experiences to changes in instructors' observation.

The last proposal is a comparative study among primary and secondary schools with respect to instructor job satisfaction and perceptions of administration that would enable researchers to decide similitudes and contrasts among various school levels.

\section{Conflicts of Interest}

The authors declare no conflicts of interest regarding the publication of this paper.

\section{References}

Abd-Hamid, S. R., Syed-Hassan, S. S., \& Ismail, N. H. (2012). Teaching Quality and Performance among Experienced Teachers in Malaysia. Australian Journal of Teacher Education, 37, 84-103. https://doi.org/10.14221/ajte.2012v37n11.2

Avolio, B. J., \& Bass, B. M. (2004). Multifactor Leadership Questionnaire. Manual and Sampler Set (3rd ed.). Mindgarden.

Aydin, A., Sarier, Y., \& Uysal, S. (2013). The Effect of School Principals' Leadership Styles 
on Teachers' Organizational Commitment and Job Satisfaction. Educational Sciences. Theory \& Practice, 13, 806-811.

Bass, B. M. (1990). Handbook of Leadership: Theory, Research and Managerial Applications (3th ed.). Free Press.

Bass, B. M., Avolio, B. J., Jung, D. I., \& Berson, Y. (1985). Predicting Unit Performance by Assessing Transformational and Transactional Leadership. Journal of Applied Psychology, 88, 207-218. https://doi.org/10.1037/0021-9010.88.2.207

Clarke, S., \& O’Donoghue, T. (2016). Educational Leadership and Context: A Rendering of an Inseparable Relationship. British Journal of Educational Studies, 65, 167-182. https://doi.org/10.1080/00071005.2016.1199772

Hallinger, P. (2014). Reviewing Reviews of Research in Educational Leadership: An Empirical Assessment. Educational Administration Quarterly, 50, 539-576. https://doi.org/10.1177/0013161X13506594

Hill, V. (2013). Principal Leadership Behaviors which Teachers at different Career Stages Perceive as Affecting Job Satisfaction. Ph.D. Thesis, Western Michigan University.

Ibrahim, M., Ghavifekr, S., Ling, S., Siraj, S., \& Azeez, M. (2013). Can Transformational Leadership Influence Teachers' Commitment towards Organization, Teaching Profession, and Student Learning? A Quantitative Analysis. Asia Pacific Education Review, 15, 177-190. https://doi.org/10.1007/s12564-013-9308-3

Ismail, M. Z. (2010). Teachers' Perception of Principal Leadership Styles and How They Impact Teacher Job Satisfaction. Ph.D. Thesis, Colorado State University.

Khan, M., Ramzan, M., Ahmed, I., \& Nawaz, M. (2011). Transactional, Transformational and Laissez Faire Styles of Teaching Faculty as Predictors of Satisfaction, and Extra Effort among the Students: Evidence from Higher Education Institutions. Interdisciplinary Journal of Researchin Business, 194, 130-135.

Lawrence, A. S. \& Vimala, A. (2012). School Environment and Academic Achievement of Standard IX Students. JournalofEducation.

Lewin, K. (1946) Action Research and Minority Problems. Journal of Social Issues, 2, 34-46. https://doi.org/10.1111/j.1540-4560.1946.tb02295.x

Maslow, A. H. (1943). A Theory of Human Motivation. Psychology Review, 50, 370-396. https://doi.org/10.1037/h0054346

Paracha, M. L. T., Qamar, A. Mirza, A., \& Waqas, I. (2012). Impact of Leadership Style (Transformational and Transactional Leadership) on Employee Performance and Mediating Role of Job Satisfaction Study of Private School (Educator) in Pakistan. GlobalJournal of Management and Business Research, 12, 54-64.

Robinson, V. M. J., Lloyd, C. A., \& Rowe, K. J. (2008). The Impact of Leadership on Student Outcomes. An Analysis of the Differential Effects of Leadership Types. Educational Administration Quarterly, 44, 635-674. https://doi.org/10.1177/0013161X08321509

Spector, B. (1995) The Sequential Path to Transformation Management. European Management Journal, 13, 383-389. https://doi.org/10.1016/0263-2373(95)00031-F

Verma, N. (2012). The Perceived Leadership Styles of Principals and their Effectiveness: A Case Study of Private Schools in UAE. Thesis, Al Ghurair University.

Viswanathan, R. (2015). Impact of Transformational Leadership on Team Effectiveness: A Study of Team Leaders in It Sector. International Global Journal for Research Analysis, 4, 405-408.

Waters, K. K. (2013). The Relationship between Principals' Leadership Styles and Job Satisfaction as Perceived by Primary School Teachers across NSW Independent Schools. Ph.D. Thesis, University of Wollongong. 